\title{
Kiss Szilvia*: Megállapítási és marasztalási perek összehasonlítása, megállapítási keresetek speciális feltételei
}

Debreceni Jogi Műhely, 2014. évi (XI. évfolyam) 1-2. szám (2014. június 30.)

\section{EIméleti alapvetés: a kereset fogalma, osztályozása}

Kezdő gondolatnak vethető fel a Pp. azon rendelkezése, melyben rögzíti, hogy a bíróság a polgári ügyek körében felmerült vitát csak erre irányuló kérelem esetén bírálja el[1]. Elörevetítendő, hogy e rendelkezésből háromirányú megállapítás tehető: a szóban forgó kérelmet keresetnek hívják, ami előterjesztésére lényegében csak a vitában érdekelt fél jogosult. E keresetet pedig a bíróság hivatott elbírálni[2]. A kereset a polgári peres eljárás legfontosabb perbeli cselekménye, a keresetnek a bírósághoz történő benyújtása a polgári peres eljárás megindításának előfeltétele[3].

A keresetről ugyanakkor igényként is beszélhetünk, mely igénynek a bíróság tehet eleget, ha teljesíti az állam által garantált igazságszolgáltatási tevékenységből fakadó kötelezettségeit. Mindezt úgy teheti meg, ha a kereset megvizsgálása után megteszi a szükséges intézkedéseket, vagyis bírósági jogvédelmet biztosít a felperes számára, mely esetet tekintve a jogvédelem eszköze maga az érdemi ítélet. A keresetlevél benyújtásával létrejön egy - a felperes és a bíróság közötti - közjogi jogviszony, mely alapját jelenti a bírósági jogvédelemnek, az érdemi ítélet iránti igénynek. E közjogi jogviszony tartama a bíróságnak a keresetlevél alapján tett intézkedéseitől függ: megszünhet a keresetlevél idézés kibocsátása nélkül, és véget érhet érdemi ítélettel - azaz határozattal - is[4].

A kereset tehát a polgári per útján érvényesíthető alanyi jog bírósági védelmének elsődleges eszköze, a keresettel megindítható polgári per pedig a bírósági jogvédelem legfontosabb és legtipikusabb - bár korántsem kizárólagos - formája. A kereset fogalmában megjelenő elsődlegesség úgyis értelmezhető, hogy a kereset sorrendben a felperes első perbeli cselekménye, és mint ilyen, a peres eljárás megindításának az előfeltétele, ugyanis kereset nélkül nincs per[5].

A kereset mindig valamely alanyi jog érvényesítését szolgálja, vagyis jogvédelemre akkor kerülhet sor, ha az érvényesíteni kívánt alanyi jogot megsértik, vitatják vagy veszélyeztetik. E tétel nem feltétlenül jelenti a perbevitt alanyi jog valóságos létezését, de mindenképpen szükséges a keresetindításhoz az alanyi jog vagy annak hiányának állítása a felperes részéröl. A Pp. a keresetlevelet teszi a perindítás eszközévé[6].

Különbséget kell tennünk a kereset és a keresetlevél között. A keresetlevél az az írásbeli beadvány, amely a keresetet és a per megindításához szükséges egyéb adatokat tartalmazza, és amellyel a felperes a bírósághoz fordul, majd alanyi jogát vagy feltételezett alanyi jogát érvényesíti.

A magyar jogirodalom különbséget tesz a kereset tárgya, illetőleg tartalma között. Elöbbin az érvényesíteni kívánt jogot, utóbbin a bíróság döntésére irányuló határozott kérelmet kell érteni.

Megjegyzendő, hogy a kereset tárgya a követelésen vagy jogon kívül olyan anyagi jogviszony is lehet, amely a perben vitássá tehető, mint például a szerződés érvényessége vagy az apaság megállapítása.

A kereset tartalma a felperes határozott kérelme arra vonatkozóan, hogy milyen jogvédelmet kíván a bíróságtól. Így tehetünk különbséget a kereset különböző fajtái, nevezetesen a marasztalási, a megállapítási és a jogalakítási kereset között.

A kereset tartalmában tehát a kereset célja is kifejezésre jut, ugyanis a kereset tárgyának és tartalmának a megjelölése a keresetlevél legfontosabb kellékei közé tartozik[7]. 


\section{A marasztalási keresetről}

A marasztalási keresetben lényegében a felperes megsértett alanyi jogának helyreállítására kéri kötelezni az alperest. A marasztalási kereset tárgya a megsértett alanyi jogból, a vitás anyagi jogi jogviszonyból származó követelés, tartalma pedig a felperes kérelme aziránt, hogy a bíróság kötelezze az alperest meghatározott tevékenységre, az attól való tartózkodásra; föszabályként marasztalási kereset csak lejárt követelések esetén érvényesíthető.

A marasztalási keresetek két csoportba oszthatók attól függően, hogy az alperestől milyen jellegü magatartás várható el:

- pozitív marasztalás kereset esetén tevőleges magatartást várnak el az alperestől (meghatározott pénzösszeg fizetése, dolog adása, szolgáltatás nyújtása, tevékenység kifejtése);

- negatív marasztalási kereset esetén a felperes kéri a bíróságtól, hogy kötelezze az alperest valamely tevékenységtől való tartózkodásra, valaminek az abbahagyására, türésére vagy nem tevésre (leggyakrabban birtokháborítás megszüntetésére, további birtokháborítástól való eltiltásra irányulnak, de előfordul a zálogtárgyból való kielégítés türésére kötelezés, a telki szolgalom gyakorlását akadályozó magatartástól való eltiltás iránti per is)[8].

A marasztalásra irányuló kereset feltételeiként tartjuk számon a felperesi jogok valóságos vagy a felperes által vélt sérelmét, illetve a követelés esedékességét[9]. A jogirodalomból vett példa szerint a marasztalásra irányuló keresetnél egy olyan hitelezőadós viszonyt szükséges feltételeznünk, ahol a hitelezö-felperes már jogosult a teljesítés követelésére, az adós-alperes pedig már teljesíteni tartozik[10].

A bírói gyakorlatból vett fontos megállapítás, hogy az ellenérték egy részének megfizetésére irányuló kereset érdemi elbírálásának elökérdéseként a vállalkozói díj helyes összegének a meghatározására van szükség, nem teszi a keresetet megállapításra irányulóvá[11]; a köteles rész iránti igény esetén pedig a kereseti kérelemnek marasztalásra kell irányulnia, és meg kell határozni azt az összeget, amelyet a jogosult a köteles rész kielégítése címén igényel[12].

Leszürhetjük tehát azt a következtetést, hogy amennyiben marasztalás lehetséges, elsődlegesnek tekinthetjük, ez esetben a megállapítás szinte kizárt. A későbbiekben láthatjuk majd, hogy ez a szigorúság nem mindig érvényesül a joggyakorlatban.

Amennyiben a felperes követelése időelötti, a bíróság a keresetlevelet idézés kibocsátása nélkül elutasítja[13], vagy ha e körülményt később észleli, a már megindult pert megszünteti[14].

Az idő előtt indított pert nem lehet megszüntetni, ha a követelés a határozat meghozatala előtt lejárt[15]; a törvényhozó ez esetben a felperesre nézve méltánytalan döntés meghozatalának a lehetőségét küszöböli ki, a teljesítési határidő lejárta előtt indított per nem szüntethető meg, ha a követelés a határozat meghozatala előtt lejárt.

Megjegyezte a Kúria, hogy megszűnt szerződés alapján járó követelés iránti keresetlevél időelőttiség okából nem utasítható el idézés kibocsátása nélkül (BH. 2007.37), illetve elvi jelentőségű tételként fogalmazta meg, hogy a végrendelet érvénytelenségének megállapítására irányuló kereset elutasítása esetén a kizárt örökös nyomban a köteles rész kiadását (teljesítést) kérheti (BH. 1988.230. III.)[16].

Felmerül a kérdés: a követelés lejártságára vonatkozó követelménytöl el lehet-e tekinteni? A válasz igenlő a következő esetekben:

a) tartásdíj, járadék vagy más időszakos szolgáltatás iránt indított perben a marasztalásra irányuló kereseti kérelem le nem járt szolgáltatásokra is előterjeszthető, ide értve: tartási és életjáradéki szerződésből eredő tartásdíj vagy életjáradéki követelések, öröklési szerződésből eredő tartásdíj, illetve életjáradéki követelések, baleseti járadék iránti igények, tartást pótló járadékkövetelések[17], családjogi jogviszonyon alapuló tartásdíj követelések, egyéb időszakosan visszatérő szolgáltatások (pl. tulajdonostárs által fizetendö többlethasználati díj)[18]; 
A Legfelsőbb Bíróság $P K$. 52. sz. állásfoglalása alapján baleseti járadékkövetelés esetén a járadékkövetelésre vonatkozóan - az elévülési időn belül - visszamenőlegesen csak meghatározott korlátok között érvényesíthető igény[19], vagyis a hat hónapnál régebben lejárt és alapos ok nélkül nem érvényesített igény bírósági úton többé nem érvényesíthető[20]. A jövőben esedékes járadékot tekintve viszont a Pp. 122. § (2) bekezdése veendö figyelembe, mely szerint tartásdíj, járadék és más időszakos szolgáltatás iránt indított perben marasztalásra irányuló kereseti kérelem a le nem járt szolgáltatásokra is előterjeszthető[21].

Ide tartozó elvi jelentőségü tétel: baleseti járadék megállapítására akkor is sor kerülhet, ha a kötelezett által beszámítani kért biztosítási összeg a lejárt járadékok összegét meghaladja; az ilyen kereseti kérelem ugyanis nem megállapításra, hanem jövőre szóló marasztalásra irányul[22].

b) Lakás, más helyiség vagy egyéb ingatlan visszabocsátása iránt a kereseti kérelem már a visszabocsátási kötelezettség előtt előterjeszthető, feltéve, hogy a visszabocsátásnak határozott időpontban kell történnie (pl. határozott idejü bérleti jogviszony esetén); ezzel a törvény azt kívánja biztosítani, hogy a per az esedékesség időpontjában lehetőség szerint már befejeződjön, és ez által a jogosultnak végrehajtható ítélet álljon rendelkezésére;

Mindkét kivételt engedő rendelkezés indoka a célszerüség, míg azonban az a) pont esetében az esetleges veszélyeztetettségre, a b) pont esetében a jogi tárgy (birtokvédelem) kiemelt védelmére tekintettel van lehetőség a követelés lejártságától való eltekintésre[23].

\section{Megállapítási keresetek feltételei: miben rejlik a specialitásuk?}

A marasztalási kereset kapcsán került megemlítésre, hogy ez az igény magában foglal egy kérelmet is aziránt, hogy a bíróság állapítsa meg a felperes jogának és az alperes kötelezettségének fennállását. A megállapítási kereset annyiban más, hogy az kifejezetten erre irányul anélkül, hogy az alperes marasztalása szóba kerülne.

Polgári perrendtartásunk mellőzi a megállapítási kereset tárgyának és fajainak a megjelölését, ami pótlandó lenne, ugyanis így a gyakorlat nélkülözi a szükséges útmutatást, melynek folytán a felperes is bizonytalanságba kerülhet a preventív jogvédelem körére nézve. Mégsem képezheti vita tárgyát az, hogy a megállapítási kereset valamely jog vagy jogviszony fennállásának vagy fenn nem állásának bírói megállapítására irányulhat. Így azonban, hogy a törvény hallgat a megállapítási kereset tárgyáról, lehetőséget kap a gyakorlat az alkalmazási kör kitágítására.

A Pp. 123. §-a nem szól a megállapítási kereset fajtáiról: a pozitív és negatív megállapítási keresetről[24].

A pozitív megállapitási kereset egyik tipikus példája lehet az okirat valódiságának, ill. hamis voltának a megállapítása, valamint a Ptk. 84. § (1) bekezdés a) pontja is ilyen lehetőséget rögzít: ha valakit személyhez füződő jogában megsértenek, az követelheti a jogsértés megtörténtének bírósági megállapítását.

A Pp. 159. § (2) bekezdése pedig a negatív megállapitási kereset egyik speciális esetét nevesíti: ha a felperes elmulasztja az első tárgyalást és emiatt az alperes kérelmére a per megszüntetésére kerülhet sor, az alperes a per megszüntetésére irányuló kérelemmel együtt a felperes ellen viszontkeresetet indíthat annak megállapítása iránt, hogy a felperest a keresetben érvényesített jog nem illeti meg[25].

Annak, hogy megállapításra irányuló keresetet lehessen indítani, két konjunktív jogszabályi feltétele van: a jogvédelem szükségessége és a teljesítés követelésének kizártsága.

Az egyik feltétel hiánya a kereset elutasitásához vezet, pusztán a Pp. 123. §-ban írt feltételek hiánya miatt; ilyen esetekben a per megszüntetésének nincs helye (ez azon ritka esetek egyike, amikor a bíróság nem érdemi kérdésben hoz ítéletet)[26]. Ezektől a feltételektől a 
törvény csak a számadási kötelezettség megállapítása iránti keresetnél tekint el, amellyel együtt a felperes az általa előterjesztett számadás helyességének megállapítását is kérheti[27].

A feltételeket a korábbi Legfelsőbb Bíróság következőképpen cizellálta:

- megállapítási kereset alaptalansága esetén sem kerülhet sor a pernek időelöttiségre hivatkozással való megszüntetésére, a kereset elutasításáról ítélettel kell rendelkezni[28];

- szükséges továbbá valamely jogviszony megléte, ugyanis nem indítható megállapítási kereset jogviszony hiányában: „tévedésbe esett a másodfokú bíróság, amikor azt állapította meg, hogy a felperesek az alperes ellen alappal terjeszthettek elő megállapítási keresetet, ugyanis az alperes semmiféle, a felperesekre kiható határozatot sem hozott, így vele szemben a felperesek megállapítási keresetet sem terjeszthettek elő'[29];

- a megállapítási kereset tárgya csak a polgári jogi - magánjogi jogviszony lehet[30]; közigazgatási jogviszonyból eredö kötelezettséggel összefüggésben megállapítási per polgári ügyben eljáró bíróság előtt nem indítható[31].

\section{A) A jogvédelem szükségessége}

A jogvédelem szükségessége vagy másképpen a jogvédelmi szükséglet, amelyről a magyar Pp. csak a megállapítási keresettel kapcsolatban tesz említést, a perjogi dogmatika egyik vitatott fogalma. A jogvédelmi szükséglet nemcsak a keresetindításnak, hanem valamennyi percselekménynek, végső soron tehát a jogvédelem teljesítésének is az általános előfeltétele. Ez az igen túlzó álláspont jogpolitikailag igen nagy veszélyeket rejt magában, de szerencsére nem tudott gyökeret verni a jogirodalomban[32].

A jogvédelem szükségessége fennáll például, ha a szerződés alapján a bank - végrehajtási záradékolás, illetve perindítás nélkül - beszedési megbízás alapján a követelt összeget leemelheti a kötelezett bankszámlájáról[33].

Egységes a bírói gyakorlat azon megállapítással kapcsolatban, mely szerint a jogvédelem szükségességének hiányában nem inditható megállapitási kereset. Az elutasító döntések okaként definiálhatjuk, hogy a felperes nem jelöli meg, hogy jogainak az alperessel szemben való megóvása végett miért szükséges a konkrét megállapítás.

Nem jelenik meg a megállapítási kereset előterjesztéséhez szükséges jogmegóvási érdek, amennyiben a szerződés felek között vitás értelmü rendelkezése - szerződésértelmezési vita van terítéken[34].

Nem inditható megállapitási kereset akkor sem, ha a jogvédelem szükségessége nem az alperessel, hanem a perben nem álló harmadik személlyel szemben áll fenn, továbbmenve, ha a felperes a bíróság felhívása ellenére sem vonja perbe azt a harmadik személyt, akinek a perben állása a jogainak megóvásához nélkülözhetetlen, a bíróság a keresetlevelet elutasítja[35].

Következetes az ítélkezési gyakorlat azzal kapcsolatban, hogy nincs helye megállapitási keresettel szemben elévülésre hivatkozásnak. Abból fakadóan, hogy az elévülés intézményét a követelésekre vonatkozóan anyagi jogi jogszabály (Ptk., valamint az Mt.) szabályozza, ez a jogintézmény a felperes által elöterjesztett eljárásjogi jogszabályban rögzített megállapítás iránti kereset elbírálása során nem érvényesül. Megállapítás iránti kereset esetében pedig nincsen olyan követelés, amelynek a teljesítésére ezen eljárásban kerülhetne sor. Ebből következően az elévülésről elfoglalt bírósági álláspontok tévesek[36].

Megjegyzendő ugyanakkor, hogy nincs helye keresetindításnak annak megállapítása iránt, hogy az alperesnek elévülés folytán nem áll fenn érvényesíthető követelése a felperessel szemben. Jelen esetben a Pp. 123. §-ban foglalt feltételek egyike sem állt fenn. A rendelkezésre álló adatok alapján az állapítható meg, hogy a felszólításokon kívül az alperes mást nem tett a követelés érvényesítése érdekében. Amennyiben az alperes a felperessel szemben pert indít, az elévülésre a felperes bármikor hivatkozhat, ez a joga nem szünik meg. 
Ezért a felperesnek nincs olyan joga, amelynek az alperessel szemben való megóvása szükséges lenne[37].

\section{B) Indítható-e megállapítási kereset semmis szerződés tekintetében?}

A megállapítási keresetek körében vitára ad okot időszakonként az a kérdés, hogy semmis szerződés tekintetében megállapítási kereset indítható-e vagy sem.

A BH. 1980. évi 136. sz. jogesete úgy foglalt állást, hogy semmis szerzödés semmisségének megállapitása iránt helye van megállapitásra irányuló kereseti kérelemnek. A szóban forgó jogeset értelmezte a Ptk. 234. § (1) bekezdéséhez füzött miniszteri indokolást is, mely jogszabály szerint semmisség megállapításához nincs szükség külön eljárásra, ennek azonban nem mond ellent az, hogy a semmisség megállapítása céljából pert is lehet indítani. Ilyen megállapítási kereset elöterjesztésének a Pp. 123. § értelmében is helye van, mert ez a felperes jogainak megóvása, a későbbi viták elkerülése végett szükséges.

Ellentétes álláspont derül ki a BH. 1991.107. sz. jogesetből az alapján, hogy a semmisséghez füzödö jogkövetkezményeket hivatalból kell levonni, arra bármikor határidö nélkül lehet hivatkozni, ebből pedig értelemszerüen következik, hogy külön megállapítás szükségtelen, ezért ilyen megállapítási kereset indításának helye nincs[38].

Egy 2008-as jogesetből mégis az derül ki, hogy a bírói gyakorlat elismeri a semmisségi megállapitási keresetindítási jogosultságot abban az esetben is, ha a fél a semmisség jogkövetkezményeinek a levonását nem kéri, de a megállapítási keresetindításnak a Pp. 123. §ban meghatározott feltételei fennállnak. Nem kétséges, hogy a felperes az alperesektől teljesítést (semmisség jogkövetkezményeinek levonását) nem igényelhetett. Ugyanakkor jogainak megóvása érdekében a semmisség megállapítása iránti keresetindítás másik konjunktív feltétele, a jogmegóvási igény fennállása a felperes jogi érdekeltsége körében kifejtett indokok alapján szintén fennállt[39].

Kiderül tehát: lehetséges a szóban forgó kereset előterjesztése. Pontosítva az irányvonalat: a szerződés érvénytelenségének megállapítására irányuló keresetet csak a szerződést kötő felek terjeszthetnek elő, 3. személy csak akkor, ha a megállapítási kereset eljárási feltételei fennállnak[40]. Továbbá a megállapítási kereset eljárásjogi feltételei nem állnak fenn, ha a kereseti kérelem tartalmából kitűnik, hogy a kötelem érvénytelenségének megállapítása iránti igény önálló megállapítási keresetként való előterjesztésével a felperes valójában egy majdani tulajdoni igényének jogalapját kívánja megteremteni. A jogalap megállapítása érdekében önálló megállapítási per nem indítható, mivel ilyen esetben marasztalás kérhető[41].

\section{C) A teljesítés kizártságának követelménye}

A megállapítási kereset benyújtásának másik feltétele az, hogy valamely okból kizárt legyen a teljesités követelése[42]. Amennyiben van lehetőség a teljesítés követelésére, kizárólag marasztalási kereset terjeszthető elő.

A teljesítésnek a kötelezett hibájából történő elmaradása esetén, a lehetetlenülés jogkövetkezményeként kártérítés követelhető, megállapítási kereset azonban nem terjeszthető elő[43].

Nincs helye csupán kártéritési felelösség megállapitására irányuló kereseti kérelemnek, ha a jogosult kártérítési is követelhet, mert a kár összege ismert: „a felperesek kereseti kérelmükben az alperes kártérítési felelősségének a megállapítását kérték". Az adott esetben azonban a megállapítási per indításának a jogszabályban megkívánt feltételei hiányoztak, ugyanis a kár pontos összege meghatározható, és nem volt akadálya a felperesek részéről a Ptk. 310. §. alapján az alperesekkel szemben marasztalásra irányuló kereset előterjesztésének[44].

A dolgozó nem indíthat keresetet a munkáltatója ellen csupán annak megállapítása iránt, hogy üzemi balesetet szenvedett, ha a munkáltató összegszerü marasztalásának nincs akadálya[45]. 
A fegyelmi eljárásra vonatkozó garanciális szabályok súlyos megsértése önmagában megalapozza a megállapításra irányuló kereset előterjeszthetőségének jogát[46].

A megállapítási kereset sajátosságai a kereset benyújtásától a per folyamán végig megjelennek, az ítélet jogerőre emelkedését követően is hatnak. Szükebb az alperes ellenkérelmi lehetősége, amiért nincs lehetősége beszámítási kifogás érvényesítésére, mivel ennek előfeltétele, hogy az a teljesítésre felperes által állított lejárt követeléssel szemben legyen előterjeszthető, ami a megállapítási pernél fogalmilag kizárt. Akadálytalan viszont az, hogy a felperes a kereset megváltoztatásával váltson át marasztalási, vagy éppen ilyen tárgyú kereseti kérelem előterjesztése esetén megállapítási keresetre. Előbbire akkor kerülhet sor, ha a megállapítási per folyamatban léte alatt már a teljesítésre is lehetőség nyílik. Utóbbira akkor kerül sor, ha a per folyamán derül ki, hogy marasztalásnak nincs még helye. A keresetfajták közötti váltásnak tehát nincs akadálya[47].

\section{A megállapítási és marasztalási kereset összehasonlítása}

Úgy gondolom, a megállapítási kereset tartalmát és következményeit tekintve is szükebb a marasztalási keresetnél. A felperes célja a megállapítási kereset előterjesztésével annyi, hogy a bíróság ítélettel tisztázza, hogy valamely jogviszony fennáll-e, vagy sem, ezen túl az alperes tevőleges magatartását, teljesítését, esetlegesen tevékenységtől való tartózkodását nem igényli. Ebböl következik a végrehajtás hiánya is, a helyt adó bírósági ítélet csak a perköltségben marasztalást kimondó részében hajtható végre.

A megállapítási és a marasztalási kereset viszonyával kapcsolatban a Kúria az EBH 2005/955. sz. elvi határozatában fejtette ki véleményét. Eszerint, ha a felperes marasztalást követelhet, úgy a Pp. 123. §-a szerint megállapítási keresetnek nincs helye. Abban az esetben, ha teljesítést nem követelhet, megállapítás iránti kereset előterjesztésének csak akkor lenne helye, ha a kért megállapítás a jogainak az alperessel szemben való megóvása végett szükséges[48].

Egy eseti döntésében pedig azt állapította meg a Kúria, hogy a Pp. 123. § rendelkezése a felperest nem akadályozta abban, hogy az alperesekkel szemben az alperesek között létrejött adásvételi szerződés érvénytelenségének a megállapítását kérje. A felperes az alperesektől teljesítést nem kérhet, a perbeli szerződés kapcsán az alperesek állnak egymással szerződéses jogviszonyban, a felperes tehát a szerződés folytán velük szemben semmilyen teljesítést nem követelhet. A perbeli szerződéssel kapcsolatban az eredeti állapot helyreállítása jogcímén sem kérhet a felperes semmilyen teljesítést, mert nem volt szerződő fél[49].

Vannak azonban olyan esetek, amikor a megállapitási és marasztalási kereset összekapcsolható, így például: a személyiségvédelem eszközei közül a Ptk. 84. § (1) a)-d) pontjai minden esetben megállapításra vonatkozó kereseti petítumot tesznek lehetővé, míg az e) pont alatti kártérítési követelés pedig már marasztalás iránti kereseti követelést fogalmaz meg. A Ptk. felhívott rendelkezései szerint, akit személyhez füződő jogában megsértettek, követelheti a jogsértés megtörténtének bírói megállapítását. Ez is megállapítási kereset, amelyre hozott ítélethez nem kapcsolódik a végrehajthatóság; ha a felperes ilyet akar elérni, a Ptk. 85. § (1) bek. b)-d) pontjában vagy a (2) bekezdésében foglalt marasztalási keresetet kell támasztania. $\mathrm{Az}$ a) pont szerinti megállapítási kereset sajátossága abban áll, hogy az közvetlenül nem vagyoni jellegü szankcióként nem jogveszélyeztetés, hanem jogsértés esetére szól, viszont kimerül a jogsértés bírói megállapításában, és ebben különbözik a marasztalási keresettől, amely már a jogsértés abbahagyására, a jogsértő eltiltására a további jogsértéstől, a sérelmes helyzet megszüntetésére, elégtétel adására, a jogsértést megelőző állapot helyreállítására irányul. Az a felperes, aki ilyen megállapítási keresetet indíthat, ugyanezen bekezdés b)-d) pontja alapján az eset körülményeihez képest a megállapításon túl marasztalást követelhet. 
A marasztalási keresetnél a Pp. kifejezetten nem említi feltételként a felperes marasztaláshoz füzödö jogi érdekét, ez persze nem jelenti azt, hogy ilyen jogi érdekről nincs szó. Megvan, csupán nem szükséges kifejezetten megemlíteni, hiszen az a marasztalási igény jellegéből magától értetődően következik.

Másként áll a dolog a megállapítási keresetnél, amelynek feltételét a törvény pontosan körülírja, amikor ahhoz az alperes érdekében a megállapítási érdeket, a megállapítás szükségességét kifejezetten megkívánja.

A megállapítási keresetnek helyt adó ítélet bizonyosan korlátozza a később eljáró marasztalási per bíróságának a döntési jogkörét, éppen ebben van a megállapítási kereset értelme. Figyelembe kell azonban venni, hogy az ilyen megállapítási ítélet jogeröhatása csak a döntéshez kötöttséget jelenti és nem egyúttal az ítéleti tényelemek jogeröre emelkedését is.

Ahol marasztalási kereset lehetséges, a pusztán megállapításra irányuló jogi érdek rendszerint hiányzik; vannak azonban esetek, amikor a marasztalási kereset lehetösége mellett is helye van megállapításnak.

Az a kiindulás, hogy a teljesítés lehetősége esetén teljesítésre és nem pozitív megállapításra kell perelni, elméletileg sem helytelen. A megállapításra irányuló jogmegóvási érdek általában hiányzik, ha a felperes már teljesítésre is perelhetne. Az alperest ilyenkor a felesleges többszöri perlés ellen a már kifejtett okokból kell megvédeni.

Azt azonban nem lehet kivételt nem türö szabályként kimondani, hogyha a felperes marasztalást követelhet, nincs helye megállapításnak. Vannak ugyanis a magyar jog szerint is esetek, amikor megállapítási keresetnek akkor is helye van, ha marasztalási kereset indítható. Ezen kívül vizsgálni kell a teljesítés követelhetőségének hiányát is.

Példaként hozható fel a tartásdíj, járadék és más időszakos szolgáltatás esetén a lejárat előtti megállapítási kereset indításának lehetősége. Erre van lehetőség, ugyanis teljesítés a lejárat hiányában nem követelhető még, és így fennáll a Pp. 123. §-ban írt egyik előfeltétel, de a 122. $\S(2)$ bek. szerint marasztalás is előterjeszthető.

Meg kell engedni a megállapítási keresetet minden olyan esetben, amikor az az eljárást a marasztalási keresethez viszonyitva egyszerüsiti, melyre akkor kerül sor, ha várható, hogy az alperes a marasztalási kötelesség és a mögötte álló végrehajtási lehetőség nélkül egyedül a megállapítási ítélet alapján is teljesíteni fogja a kötelezettségét, ami különben a közbenső ítéletnek is pergazdaságossági szempontja.

A megállapítási keresetnek csupán a polgári perútra terelt ügyekben van helye; ez a korlátozás a marasztalási keresetre is áll. Az a kör azonban, amelyet valamely jog vagy jogviszony fennállásának vagy fenn nem állásának a megállapítása átfog, igen széles és ebben a marasztalási keresettől a megállapítási nem különbözik. Figyelembe jönnek a dologi és kötelmi jogi, ahogy a munkajogi és családjogi területekre eső jogok és jogviszonyok egyaránt[50].

\section{Összegzés}

Összegezve az elmondottakat, a Polgári perrendtartásról szóló törvényünk nem korlátozta oly széles körben a megállapítási keresetek körét, mint ahogy azt gondolnánk, hanem általános, önálló jogvédelmi eszköz minőségű keresetként tartja számon.

A kivételt is engedö, rugalmasabb értelmezés elismeri a megállapítási kereset jogosultságát akkor is, ha a felperes egyébként már marasztalási keresetet is terjeszthetne elö. Kategorikusan nem jelenthető ki, hogyha marasztalási kereset indítható, megállapításinak nincs helye.

Kiküszöbölendő a hiányosság, hogy a Pp. nem tartalmazza a megállapítási kereset tárgyát és fajait. Ami pedig a megállapítási kereset kiegészítő jellegét illeti, e tétel erősségét a marasztalási per lehetősége mellett is megindítható megállapítási keresetek köre rögtön csökkenti. A szubszidiaritás hiányát éppen az mutatja meg, hogy a marasztalás kérésének a 
lehetősége nem mindig zárja ki a megállapítási keresetet, amelynek önálló, sajátos célja van, és nem merül ki abban, hogy pusztán előzménye legyen egy későbbi marasztalási pernek.

\title{
Comparison of condemnation and declarative litigation, special conditions of declarative claims - Summary
}

For the first, I think that it is necessary to make clear what action is.

The action the application to the proposal of which the half interested in the debate is entitled and the court passes judgement on it. Bringing an action to the court is the prerequisite of the setting in motion of the civil action procedure.

The plaintiff asks it for the restoration of his violated subjective right practically in the action of detaining to oblige the defendant. The object of the action of detaining the claim originating from the violated subjective right, the controversial material legal contractual relationship, his content though the plaintiff's application, that let the court oblige it defendant onto a particular activity, abstaining from it.

Basic rule: action of detaining expired in case of claims only enforceable. The action of assessment in so much action of detaining, that it positively aims at the court establishing it for the plaintiff's right and the existence of the defendant's asking to stay being mentioned.

It being possible to initiate action of assessments has two conditions conjunctive: the legal defence for the claim of his necessity and the impossibility of the vindication. The content and the consequences of the action of assessment considering too narrower than the action of detaining.

The plaintiff's aim in the action of assessment, that the court clears up whether one of the contractual relationships exist with a judgement or not, it does not claim him accomplishing a defendant's active behaviour beyond this. The deficiency of the execution follows from this, the giving onto an end which can be grown in the part of a judgement saying detaining in the legal charge only.

Verifiable, that the action of assessment independent legal defence device quality actions. Categorically cannot be declared, if action of detaining possible, assessment one is not eligible. The clarification of the situation and correcting him wait for the legislator however.

\author{
Irodalomjegyzék \\ Bírói gyakorlattal kapcsolatos forrás, törvényi hivatkozások: \\ BDT 2012.2648. \\ BDT 2012.2673 \\ BDT 2012.2709 \\ BDT. 2013.2883 \\ BH 1988/77.; LB P. törv. III. 20. 413/1987 \\ LB Gf. I. 30.433/2002. - EBH 2005. évi 2/955. sz. \\ LB Gf. I. 32 183/1989. - BH 1991. évi 1/33. sz. II. \\ LB Gf. III. 31 152/1982. - BH 1984. évi 11/464. sz. \\ LB M. törv. 10 081/1988. - BH 1990. évi 1/39. sz. \\ LB M. törv. 10 204/1984. - BH 1985. évi 5/252. sz.; LB Pfv. IV. 21 906/1993. - \\ BH 1994. évi 8/423. sz.; Pp. 130. § (1) g) \\ LB M. törv. I. 10220/1989. - BH 1990. évi 7/284. sz. \\ LB Mfv. I. 10025/2007. - BH 2008. évi 6/162. sz. \\ LB Mfv. II. 10 679/2000. - BH 2002. évi 6/245. sz. \\ LB P. törv. III. 20 592/1989. - BH 1990. évi 3/105. sz. \\ LB Pfv. IX. 20.142/2007. - BH. 2008. évi 6/153. sz. \\ LB Pfv. V. 22 702/2001. - BH 2004. évi 5/189. sz. \\ LB Pfv. V. 22 960/1994. - BH. 1996. évi 3/152. sz.
}


LB Pfv. VI. 21 074/1995. - BH 1996. évi 12/636. sz.

Lb Pfv. VI. 21 980/2006. - BH 2007. évi 5/154. sz.

Legfelsőbb Bíróság (továbbiakban: LB) Gf. VII. 31 505/1977. - BH. 1978. évi 5/215. sz.

PK. 52. sz. állásfoglalás

Pp. 121. § (1) bek.

Pp. 123. §

Pp. 130. § (1) bek. f)

Pp. 157. §a)

Pp. 158. § (3) bek.

Pp. 3. § (1) bek.

Ptk. 280. § (3)

\section{Internetes forrás:}

http://ptk2012.hu/wp-content/uploads/2012/10/2007-06kodi.pdf Polgári Jogi Kodifikáció, Szerkesztőbizottsági Javaslat, V. könyv: Kötelmi jog, Ötödik Rész, A felelősség szerződésen kívül okozott károkért, 10. o.

\section{Könyv, írott tananyag:}

Juhászné Zvolenszky Anikó: Polgári eljárásjogi ismeretek, Pólay Elemér Alapítvány, Szeged, 2010, 131. o.

Kapa Mátyás - Szabó Imre - Udvary Sándor: A polgári Perrendtartásról szóló 1952. évi III. törvény magyarázata, Magyar Hivatalos Közlönykiadó, 2007, 501. o.

Kengyel Miklós: Magyar polgári eljárásjog, Osiris Kiadó, Budapest, 2012, 219. o.

Kiss Daisy: A polgári per titkai, HVG-ORAC Lap- és Könyvkiadó Kft., Budapest, 2009., 415. o.

Németh János-Kiss Daisy: A Polgári Perrendtartás magyarázata 1., Complex Kiadó Jogi és Üzleti Tartalomszolgáltató Kft., Budapest, 2010, 487. o

Tölg-Molnár László: Polgári eljárásjog I., Novissima Kiadó, Budapest, 2009., 249. o.

Udvary Sándor: Polgári Perrendtartás kiegészítve jogegységi határozatokkal és a bírói gyakorlattal, Novissima Kiadó, Budapest, 2012. 116. o.

Folyóirat, cikk:

Kengyel Miklós: A jogvédelmi igény, Jogtudományi Közlöny, 1986. évi 11. szám 550-556. o

Móra Mihály: A megállapítási kereset tárgya, fajai és a jogmegóvás szükségessége, Jogtudományi Közlöny, 1961. október, 16. évf., 10. sz., 519-523. o

Novák István: A kereset a polgári perben, Budapest, 1966., 48. o.

* Hallgató, DE ÁJK jogász szak, V. évfolyam.

[1] Polgári Perrendtartásról szóló 1952. évi III. törvény (továbbiakban: Pp.) 3. § (1) bek.

[2] Kiss Daisy: A polgári per titkai, HVG-ORAC Lap- és Könyvkiadó Kft., Budapest, 2009., 415.

[3] Juhászné Zvolenszky Anikó: Polgári eljárásjogi ismeretek, Pólay Elemér Alapítvány, Szeged, 2010, 131.

[4] i.m. Kiss Daisy: 415.

[5] Németh János-Kiss Daisy: A Polgári Perrendtartás magyarázata 1., Complex Kiadó Jogi és Üzleti Tartalomszolgáltató Kft., Budapest, 2010, 487.

[6] Pp. 121. § (1) bek.

[7] i.m. Németh János-Kiss Daisy: 487. 
[8] Kiss Daisy: A polgári per titkai, HVG-ORAC Lap- és Könyvkiadó Kft., Budapest, 2009., 420-422.

[9] Tölg-Molnár László: Polgári eljárásjog I., Novissima Kiadó, Budapest, 2009., 249.

[10] Novák István: A kereset a polgári perben, Budapest, 1966., 48.

[11] Legfelsőbb Bíróság (továbbiakban: LB) Gf. VII. 31 505/1977. - BH. 1978. évi 5/215. sz.

[12] LB Pfv. V. 22 960/1994. - BH. 1996. évi 3/152. sz.

[13] Pp. 130. § (1) bek. f)

[14] Pp. 157. §a)

[15] Pp. 158. § (3) bek.

[16] Udvary Sándor: Polgári Perrendtartás kiegészítve jogegységi határozatokkal és a bírói gyakorlattal, Novissima Kiadó, Budapest, 2012. 116.

[17] vö. Ptk. vonatkozó rendelkezései

[18] Kapa Mátyás - Szabó Imre - Udvary Sándor: A polgári Perrendtartásról szóló 1952. évi III. törvény magyarázata, Magyar Hivatalos Közlönykiadó, 2007, 501.

[19] Ptk. 280. § (3)

[20] http://ptk2012.hu/wp-content/uploads/2012/10/2007-06kodi.pdf Polgári

Jogi

Kodifikáció, Szerkesztőbizottsági Javaslat, V. könyv: Kötelmi jog, Ötödik Rész, A felelősség szerződésen kívül okozott károkért, 10.

[21] PK. 52. sz. állásfoglalás

[22] BH 1988/77.; LB P. törv. III. 20. 413/1987

[23] i.m. Németh János-Kiss Daisy: 503.

[24] Móra Mihály: A megállapítási kereset tárgya, fajai és a jogmegóvás szükségessége, Jogtudományi Közlöny, 1961. október, 16. évf., 10. sz., 519-523.

[25] Kengyel Miklós: Magyar polgári eljárásjog, Osiris Kiadó, Budapest, 2012, 219.

[26] LB M. törv. I. 10220/1989. - BH 1990. évi 7/284. sz.

[27] i.m. Németh János-Kiss Daisy: 504.

[28] LB Gf. I. 30.433/2002. - EBH 2005. évi 2/955. sz.

[29] LB Pfv. VI. 21 074/1995. - BH 1996. évi 12/636. sz

[30] LB Pfv. IX. 20.142/2007. - BH. 2008. évi 6/153. sz.

[31] LB Pfv. V. 22 702/2001. - BH 2004. évi 5/189. sz.

[32] Kengyel Miklós: A jogvédelmi igény, Jogtudományi Közlöny, 1986. évi 11. szám 550556.

[33] BDT 2012.2673

[34] BDT 2012.2648.

[35] LB M. törv. 10 204/1984. - BH 1985. évi 5/252. sz.; LB Pfv. IV. 21 906/1993. - BH 1994. évi 8/423. sz.; Pp. 130. § (1) g)

[36] LB Mfv. I. 10025/2007. - BH 2008. évi 6/162. sz.

[37] LB Gf. III. 31 152/1982. - BH 1984. évi 11/464. sz.

[38] i.m. Tölg-Molnár László: 250-251. o.

[39] i.m. Németh János-Kiss Daisy: 506. o

[40] BDT. 2013.2883

[41] BDT 2012.2709

[42] Pp. 123. §

[43] LB Gf. I. 32 183/1989. - BH 1991. évi 1/33. sz. II.

[44] LB P. törv. III. 20 592/1989. - BH 1990. évi 3/105. sz.

[45] LB M. törv. 10 081/1988. - BH 1990. évi 1/39. sz.

[46] LB Mfv. II. 10 679/2000. - BH 2002. évi 6/245. sz.

[47] i.m. Kiss Daisy: 422. o.

[48] i.m. Németh János - Kiss Daisy: 506. o.

[49] Lb Pfv. VI. 21 980/2006. - BH 2007. évi 5/154. sz. 
[50] vö. Móra Mihály: 520-529. o. 